\title{
Pojęcie pola metaforycznego w poetyce kognitywnej
}

ABSTRACT. Ślosarska Joanna, Pojęcie pola metaforycznego $w$ poetyce kognitywnej IA notion of the metaphoric field in cognitive poetics]. „Przestrzenie Teorii” nr 1, Poznań 2002, Adam Mickiewicz University Press, pp. 87-96. ISBN 83-232-1238-4. ISSN 1644-6763.

The paper presents basic conceptualisations of the metaphoric field in the views of N. Babuts, G. Lakoff, M. Johnson, M. Turner, R. W. Gibbs, and R. Tsur. In the course of considering these views the following problems are discussed: differentiation of the conceptual from linguistic metaphors, hypothesis of a cognitive base for linguistic creation of poetical tropes, creation of poetical figures in relation to standard metaphors in natural language, dynamics of the processes of conceptual and linguistic metaphorisations, categories of the mental image and of the vantage point. The whole discussion is placed within a context of the two basic paradigms of cognitive science mental and empirical.

Teoretyczne podstawy pojęcia pola metaforycznego tkwią w założeniach nauk kognitywnych, integrowanych pod kątem wspólnego paradygmatu poznawczego. Do podstawowego zespołu nauk kognitywnych należą współcześnie: informatyka, lingwistyka, psychologia, neurologia i antropologia. Na gruncie tych nauk ukształtowały się dwa zasadnicze paradygmaty badawcze: mentalistyczny i empiryczny.

Wyznacznikami postawy mentalistycznej są następujące założenia: 1) przedmiotem badań naukowych są świadomości; 2) świat złożony jest z rzeczy i stanów rzeczy; 3) świadomości są symbolicznymi reprezentacjami tych rzeczy i ich stanów; 4) reprezentowanie jest przekładem symbolicznym; 5) sztuczna inteligencja reprezentuje świadomości; 6) sztuczna inteligencja, lingwistyka i psychologia zajmują się sposobami konstruowania reprezentacji oraz regułami ich przekształcania.

Wyznacznikami postawy empirycznej są natomiast założenia następujące: 1) przedmiotem badań naukowych jest mózg i procesy nerwowe; 2) świadomości nie są reprezentacjami, lecz odwzorowaniami rzeczy i stanów rzeczy w świecie; 3) świadomości nie są samoświadome, konceptualne ani symboliczne, choć można im przypisać zdefiniowaną własność subkonceptualności i subsymboliczności; 4) lingwistyki nie da się objaśnić i opisać w terminach symboli i relacji; 5) procesy kognitywne nie moga być zredukowane do funkcji świadomości, stanowią one bowiem zespół 
aktywności organizmu w środowisku; 6) w zespole tych aktywności najważniejsza jest postawa mentalna, osiągająca najwyższą wartość w językach ${ }^{1}$.

W badaniach prowadzonych na gruncie nauk szczegółowych, w tym na gruncie lingwistyki i poetyki, podstawowe założenia mentalizmu i empiryzmu nie są wyraziście rozgraniczone; nie są też zakładane jako sprzeczne, co w efekcie sprzyja kształtowaniu holistycznej perspektywy badań, równocześnie jednak staje się przyczyną dodatkowych sporów przeniesionych na dziedziny szczegółowe. W dotychczasowych ujęciach pola metaforycznego aktualizują się oba paradygmaty nauk kognitywnych, a w konsekwencji ujawniają się właśnie charakterystyczne dla kognitywizmu dystrakcje związane $\mathrm{z}$ niewspólmiernością warunków opisu badanego przedmiotu. W ramie ogólnej hipotezy pola metaforycznego zawarte jest podstawowe założenie nauk poznawczych, sankcjonujące dwuwymiarowość konceptualizacji (skanujących odwzorowań) w układach pojęcie wyrażenie językowe. Owa dwuwymiarowość to własność i efekt synchronizacji procesów poznawczych oraz szacowania werbalnego. George Lakoff i Mark Johnson w swojej Filozofii $w$ ciele, stanowiącej w dużej mierze podsumowanie dotychczasowych badań $w$ dziedzinie lingwistyki i poetyki kognitywnej, podkreślają, iż metafory językowe to nazwy odwzorowań metafor pojęciowych ${ }^{2}$. Zdaniem Lakoffa i Johnsona, jednym z największych nieporozumień związanych z teorią metafory pojęciowej (czyli bazy kognitywnej dla szacowania werbalnego) było traktowanie formuły językowej (stanowiącej z założenia układ z odwzorowaniem pojęciowym) jako znaku autonomicznego, a w konsekwencji asymilowanie procedur kognitywnych zgodnie $\mathrm{z}$ tradycyjną teorią metafor, stosowaną $\mathrm{w}$ dziedzinie wyrażeń językowych. Tymczasem wszelkie odwzorowania metaforyczne są częścią systemów pojęciowych i dotyczą nie słów, lecz pojęć krzyżujących się $w$ obrębie pola metaforycznego (równocześnie krzyżujących i transformujących dzied ziny owego pola). Rozróżnienie między metaforami pojęciowymi a językowymi wyrażeniami metaforycznymi jest warunkiem i wyznacznikiem poprawności badań w lingwistyce i poetyce kognitywnej. A oto jeden z przykładów, użytych przez autorów Filozofii w ciele dla przybliżenia założeń teoretycznych: metafora: „miłość jest podróżą”. Systematyczny proces konceptualizowania miłości jako podróży obejmuje odpowiedniości między pojęciami w dziedzinie podróży a pojęciami w dziedzinie miłości. Można to wyrazić jako rodzaj odwzorowania z pojęcio-

\footnotetext{
${ }^{1}$ F. Rastier, Sémantique et recherches cognitives, Paris 1991, s. 37-39.

${ }^{2}$ G. Lak off, M. Johnson, Philosophy in the flesh. The embodied mind and its chal. lenge to western thought, New York 1999.

${ }^{3}$ Tamże, s. 39-43.
} 
wej dziedziny Podróży (nazwanej „dziedziną źródłową") w pojęciową dziedzinę Miłości (nazwaną „dziedziną docelową”). Odwzorowanie to wygląda tak:

\section{Miłość jest podróżą}

- Podróżnicy $\rightarrow$ Kochankowie

- Pojazd $\rightarrow$ Związek Miłosny

- Podróżowanie Pojazdem $\rightarrow$ Funkcjonowanie w Związku Miłosnym

- Cele Podróży $\rightarrow$ Wspólne Cele Życiowe Kochanków

- Przeszkody dla Ruchu $\rightarrow$ Trudności w Związku

Odwzorowanie to można wyrazić w bardziej intuicyjny sposób jako:

- Kochankowie Są Podróżnikami

- Związek Miłosny Jest Pojazdem

- Funkcjonowanie w Związku Miłosnym Jest Podróżowaniem w Pojeździe

- Trudności w Związku Są Przeszkodami w Ruchu

Jak podkreślają Lakoff i Johnson, miłość nie musi być konceptualizowana jako podróż. W wielu kulturach nie ma takiej konwencjonalnej konceptualizacji miłości. W Ameryce jednak odwzorowanie takie jest dość powszechne, obejmując zarówno wzorce wnioskowania, jak i szacowania werbalnego. Konwencjonalne metafory pojęciowe stanowia, zdaniem Lakoffa i Johnsona, podstawę kreacji nowych metafor, czyli systemowego rozszerzania odwzorowania konwencjonalnego. Ta dość kontrowersyjna teza, sformułowana już wcześniej w Metaforach $w$ naszym życiu ${ }^{4}$, rozwinięta w Przewodniku polowym po metaforach ${ }^{5} \mathrm{i}$ argumentowana dodatkowo właśnie w Filozofii $w$ ciele, zbudowana jest na przeświadczeniu o ciagłości, zwrotności i izotopii składników pola metaforycznego. W kontekście podanego już przykładu („miłość jest podróżą”) Lakoff i Johnson rozpatrują „nową metaforę" - ,jedziemy pasem szybkiego ruchu po autostradzie miłości" - jako efekt rozszerzania konceptualizacji miłości w kategoriach podróży. Argumentacja ciągłości odwzorowań w polu metaforycznym jest tutaj następująca: kochankowie w związku miłosnym ,jadącym pasem szybkiego ruchu" czynią znaczne postępy w krótkim czasie. Istnieje niebezpieczeństwo, że związek się rozbije, a kochankowie zostaną zranieni. Jednak dla kochanków zarówno „szybkość związku”, jak i niebezpieczeństwo są ekscytujące. Znaczącym składnikiem tej konceptualizacji jest odwzorowanie wniosków dotyczących podróży na wnioskowanie odnoszące się do miłości, co sprawia, że wyrażenie metaforyczne „jedziemy pasem

${ }^{4}$ G. Lakoff, M. Johnson, Metaphors we live by, Chicago 1980; Metafory $w$ naszym życiu, tlum. T. Krzeszowski, Warszawa 1989.

${ }^{5}$ G. Lak off, M. Turner, More than coool reason. A fiel guide to poetic metaphor, Chicago and London 1989. 
szybkiego ruchu po autostradzie miłości" jest systemowym rozszerzeniem znanego już odwzorowania metaforycznego „miłość jest podróżą"6.

W ramach ogólnie sformułowanej standardowej teorii metafory, obejmującej także warunki tworzenia nowych metafor, Lakoff, Turner i Johnson proponują konkretny model analizy i interpretacji pojęciowych pól metaforycznych korelowanych $\mathrm{z}$ formami językowymi. Funkcję jednostki metaforycznego ciągu ma pełnić schemat obrazowy złożony co najmniej z dwóch domen. Domeny tworzą układ dziedzin - źródłowej i docelowej. Każdą metaforę można analizować przez schematy odwzorowania dziedziny źródłowej na docelową. Na każde odwzorowanie składają się: a) szczeliny konceptualne łączące obie dziedziny; b) relacje czasowe, przestrzenne, sprawcze, celowościowe, współkształtujące odwzorowania przebiegu zdarzeń; c) własności, dzięki którym obiekty realizują swoje cele; d) wiedza (sądy i wnioskowania) umożliwiająca odwzorowanie w dziedzinie docelowej wzorców wnioskowania na temat obiektu w dziedzinie źródłowej. Procesy poznawcze sterujące schematami odwzorowań opierają się na kilku podstawowych tendencjach: a) do strukturowania i wypełniania pojęć, umożliwiającego przenoszenie do struktury konceptualnej tego, czego niezależnie od metafory tam nie ma; b) do uogólniania i profilowania schematów za pośrednictwem selekcji detali pojawiających się na wyższych i niższych poziomach organizacji dziedzin; c) do projekcji wnioskowania i orzekania umożliwiającego odwzorowanie trybów rozumowania w dziedzinie docelowej; d) do wartościowania sterującego przenoszeniem ocen obiektów; e) do identyfikacji z konceptualną i ekspresywną jakością obiektów odwzorowanych, umożliwiającej automatyczne korzystanie ze standardowych i standaryzowanych w kulturze metafor ${ }^{7}$.

Uszczegółowioną problematykę dynamiki procesów metaforyzacji zaproponował Nicolai Babuts w swojej The dynamic of the metaphoric field. A cognitive view of literature (1992). W układzie pojęć teoretycznych, którymi posługuje się Babuts, najważniejszą funkcję pełnią: pole metaforyczne, znaczenie i wzorzec dynamiczny. Pole metaforyczne określa autor jako przestrzeń pamięciową, funkcjonalnie zorganizowaną $w$ relacji do aktów tworzenia i odtwarzania tekstu. W polu metaforycznym zawarte są wzorce pamięciowe ukształtowane przez sygnały językowe, percepcyjne, kulturowe i materialne. Sygnały te, pierwotnie w postaci sekwencji, wzorcują struktury podlegające transformacjom. Proces transformacji ustrukturowanych wzorców pamięciowych może być inicjowany przez sygnały językowe pod nieobecność bodźców percepcyjnych, czerpanych

\footnotetext{
${ }^{6}$ G. Lak off, M. Johns on, Philosophy in the flesh..., s. 41-42.

${ }^{7}$ G. Lak off, M. Turner, More than cool reason..., s. 63-65.
} 
$\mathrm{z}$ tła środowiska fizykalnego lub $\mathrm{w}$ synchronizacji $\mathrm{z}$ owymi bodźcami. Znaczenie sygnałów językowych jest zawsze efektem kontaminacji utrwalonych w pamięci wzorców lingwistycznych i percepcyjnych oraz schematów przewodzenia neuronowego. Przestrzeń, w której znaczenie jest wytwarzane, to przestrzeń ludzkiej świadomości, nie zaś zobiektywizowany w tekstach układ wyrażeń językowych. Jednostkami znaczenia są dynamiczne wzorce reprezentujące wizualną, słuchowa, dotykową, smakową i węchową organizację stanów percepcji, odpowiadającą tzw. percepcyjnej składni obiektów w tle środowiska fizykalnego. Różnorodne wzorce dynamiczne (znaczenia) są identyfikowane $w$ polach metaforycznych, które odwzorowują, aktualizują i transformują dominanty doświadczenia. Pola metaforyczne są ukształtowane w harmonii z ogólnym pamięciowym światopoglądem. Pomiędzy poszczególnymi polami metaforycznymi mogą zachodzić relacje krzyżowania i przekształcania wyrażające się $\mathrm{w}$ dynamice zmian jednostek znaczenia, przy czym niektóre $\mathrm{z}$ owych zmian moga się standaryzować zgodnie $z$ intersubiektywnym, kulturowym i religijnym światopoglądem. Poszczególne pola metaforyczne i ich związki nie stanowią odwzorowującej reprezentacji świata zewnętrznego, lecz są w stosunku do niego strategicznie paralelne. Pola stanowią zakodowany model świata, konstruowany tak, aby zachowana została w świadomości jego tożsamość. Pod nieobecność bodźców percepcyjnych, przy świadomym lub podświadomym zawieszeniu ich kopii pragmatycznych, gwarantujących tożsamość obiektów i wymiarów świata zewnętrznego, umysł może zrekonstruować pole metaforyczne zgodnie $\mathrm{z}$ emocjonalna, aksjologiczną i estetyczną intencją podmiotu. Wytwarzane w ten sposób obiekty wyobrażeniowe, wyrażane np. w języku za pośrednictwem systemu tropów poetyckich, pozostają nadal strategicznie paralelne do świata zewnętrznego. Ich specyficzną własnością jest nacechowanie pól metaforycznych taką konfiguracją znaczeń, która ułatwia wzmocnienie i rozszerzenie relacji ,ja-świat”, dzięki włączeniu w świadome przeżywanie obrazowych projekcji uczuć i wartości ${ }^{8}$.

Proponowana przez Babutsa hipoteza dynamiki pól metaforycznych związana jest $z$ podstawową dla nauk kognitywnych, w tym dla poetyki, interpretacją obrazu mentalnego $0^{9}$. Obraz mentalny (reprezentacja obrazująca) to układ treści świadomości będący efektem przetwarzania, przechowywania i odtwarzania informacji w formie wyobrażeniowej. Empiryczne badania mechanizmów poznawczych sterujących obrazami

${ }^{8} \mathrm{~N}$. Babuts, The dynamic of the metaphoric field. A cognitive view of literature, London and Toronto 1992, s. 105-120.

${ }^{9}$ Zob. na ten temat: J. Cohen, The imagery debate. A critical assessment, „Journal of Philosophical Research", vol. XXI, 1996. 
mentalnymi dopuszczają aktualnie następujące wnioski: obrazy mentalne mogą być obracane i skanowane, wydają się mieć części, subiektywne rozmiary i granice. Procesy zachodzące $w$ obrazowaniu mentalnym maja wspólne mechanizmy $\mathrm{z}$ postrzeganiem wzrokowym, $\mathrm{np}$. istnieje maksymalny kąt widzenia, który ogranicza rozmiar obrazów i który w reprezentacji obrazującej zostaje zachowany w modelowaniu centrum o najwyższej rozdzielczości oraz peryferiów i granicy, poza którą obraz się rozlewa i traci swoją autonomię. Informacja czasoprzestrzenna zawarta $w$ reprezentacji obrazującej kształtuje się także w relacji do procesów percepcji wzrokowej, np. skanowanie układu części obrazu wymaga czasu wprost proporcjonalnego do przestrzeni je rozdzielającej. Wśród najważniejszych zasad skanowania obrazów mentalnych możemy wyróżnić: powiększanie, pomniejszanie, zacieranie, przesuwanie, przemieszczanie, nakładanie, usuwanie, zestawianie, rozjaśnianie, zaciemnianie, wyostrzanie, zagęszczanie, perspektywiczne rzutowanie, zwielokrotnianie, wymiana (zastępowanie) części lub tła, lub układu części, lub układu części na tle. Wyróżnione zasady reprezentowane są $w$ takich figurach językowych, jak metafora, metonimia, synekdocha, porównanie, litotes, epitet metaforyczny, oksymoron, a także w takich sposobach semantycznego nacechowania wyróżnionych figur, jak np. animizacja i antropomorfizacja.

Koncepcje obrazowania mentalnego nie są jeszcze w badaniach kognitywnych dopracowane pod względem teoretycznym i empirycznym na tyle, by uznać je za wystarczającą podstawę dalszych badań. Możemy wyodrębnić trzy podstawowe pytania, które nadal są w centrum „debaty nad wyobrażeniami" (Cohen, 1996) i dotyczą bezpośrednio hipotezy pola metaforycznego. Sa to pytania o funkcję sądu w wyobrażeniu mentalnym, o pojęciowy aspekt czasoprzestrzennego ujmowania obiektów (tzw. "punkt oglądu" i „kąt widzenia umysłu”) oraz o zasady językowej reprezentacji (szacowania werbalnego) obrazów mentalnych, w tym o motywację i celowość używania tropów poetyckich. Pytania te występują najczęściej łącznie, choć ich ukierunkowanie i pogłębienie zależy od zakładanej dziedziny badań szczegółowych. W profilowaniu hipotez dotyczących obrazu mentalnego decydująca funkcję pełnią koncepty relacji czasoprzestrzennych, o których Lakoff i Johnson twierdzą, iż znajdują się w centrum naszego systemu pojęciowego ${ }^{10}$. Ponieważ nie widzimy relacji przestrzennych $w$ taki sposób, jak przedmioty fizyczne, to wszelki dystans między przedmiotami, wyrażany np. w kategoriach „bliżej / dalej”, ustalamy względem punktu orientacyjnego, który może mieć złożoną charakterystykę danego obiektu, aktu percepcji oraz efektu mentalnego skanowania fragmentu czasoprzestrzeni. Podobnie relacje „z przodu / z tyłu /

${ }^{10}$ G. Lak off, M. Johnson, Philosophy in the mind..., s. 16-17. 
w poprzek / w centrum / nad / pod / obok" - ich konceptualizacja związana jest ściśle $\mathrm{z}$ aktualizowanymi programami motorycznymi. $\mathrm{Z}$ chwilą ich zablokowania, skanowanie mentalne może mieć formę pamięciowej reprezentacji obrazowej (ścieżki neuronowej) powielającej utrwalone kopie pragmatyczne, lub też może być od niej odchylone zgodnie $\mathrm{z}$ indywidualnym "kątem widzenia umysłu”. Zdaniem Lakoffa i Johnsona używamy pojęć relacji przestrzennych nieświadomie i nakładamy je poprzez nasze systemy pojęciowe i percepcyjne. Automatycznie i nieświadomie „postrzegamy” jeden byt jako „w, na, w poprzek" innego bytu. Percepcja taka (swoistego rodzaju spontaniczna ontologia fizykalna) zależy od ogromnej ilości nieświadomych aktów poznawczych. Autorzy Filozofii w ciele przytaczają jako przykład następujący fragment obrazowania czasoprzestrzeni: aby zobaczyć motyla w ogrodzie, musimy dokonać projekcji struktury wyobrażeniowej o niebanalnej wielkości na scenę zdarzenia. Musimy skonceptualizować granice ogrodu jako trójwymiarowy pojemnik z wnętrzem, które rozciąga się $\mathrm{w}$ powietrzu, a następnie umiejscowić w nim motyla jako ksztalt (trajektor) względem tego konceptualnego pojemnika, który służy jako tło (landmark). Podobnie złożone czynności percepcji wyobrażeniowej wykonujemy w trakcie kazdego aktu poznawczej orientacji w środowisku ${ }^{11}$.

Robert E. MacLaury, podtrzymujący hipotezę analogii między myśleniem abstrakcyjnym a percepcją przestrzeni fizykalnej, podkreśla, iż konceptualizacja układów kształtu na tle (trajektor-landmark) jest powszechnym działaniem poznawczym, a profilowanie takich układów jest funkcją percepcyjnego i mentalnego punktu oglądu ${ }^{12}$. Zdaniem MacLaury'ego analogia między ontologiczną charakterystyką przestrzeni a jej pojęciowym obrazowaniem kształtowana jest na ściśle określonym poziomie współrzędnych, za pomocą których konstruujemy właśnie punkt widzenia. $\mathrm{W}$ domenie fizycznej współrzędne składają się z prostopadłych wymiarów i czasu jako funkcji względnego ruchu, podczas gdy w umyśle analogiczne współrzędne składają się ze specyficznych wrażeń i kognicji ${ }^{13}$. Niektóre

${ }^{11}$ Zdaniem Lakoffa i Johnsona elementarne relacje przestrzenne moga być teoretycznie rozpatrywane jako struktura złożona ze schematów obrazowych, profili i układów trajektor-landmark. Jest to w zasadzie uproszczona wersja warunków opisu scenicznego obrazowania w ujęciu R. Langackera, por. Wyktady z gramatyki kognitywnej, przek1. zb. pod red. H. Kardeli, Lublin 1995, s. 19-20.

${ }^{12}$ R. E. M a cLaury, Vantage theory, w: Language and cognitive construal of the world, Berlin-New York 1995, s. 231-276.

${ }^{13} \mathrm{Jak}$ bardzo jednak jest to problem złożony, wynikający głównie $\mathrm{z}$ niewspołmierności struktury przestrzennej umysłu (wrodzonej i wykształconej ewolucyjnie) oraz struktury przestrzeni fizykalnej, zob. A. Nowak, Wyobrażeniowe mechanizmy przetwarzania informacji: myślenie przestrzenne, Wrocław 1991. 
ze współrzędnych mentalnych mogą być przechowywane jako względnie stałe, inne natomiast mogą być względnie izolowane i poddawane przekształceniom. Uwspółzależnienie stałych i zmiennych współrzędnych pozwala konstruować perspektywy widzenia oraz szacować je werbalnie poprzez najbardziej reprezentowane (najbliższe konceptualizacji mentalnej, najbardziej znaczące) formy wyrażeń. Metafory pojęciowe i językowe to szczególny typ oglądu, skonstruowany przez ustalenie relacji dziedziny źródłowej (względnie stałe współrzędne, wrażenia i kognicje przechowywane jako kopie pragmatyczne) do dziedziny docelowej (względnie zmienne współrzędne, wrażenia i kognicje kreowane jako reprezentacja obrazująca względem nastawień emocjonalnych, psychofizycznych, aksjologicznych). Koncepcja MacLaury'ego jest teoretycznie zbieżna z poglądami Babutsa na temat dynamiki pól metaforycznych, jednak MacLaury jest bardziej ostrożny w definiowaniu kategorii wzorców dynamicznych (prototypów percepcyjnych, jednostek znaczenia), co wynika $z$ jego analitycznego podejścia do wyników badań empirycznych, odsłaniających skomplikowane zależności między procesami poznawczymi, ich zróżnicowanym psychofizycznym podłożem a sytuacją bodźcową, stanowiącą dobrze rozpoznany i świadomie założony $w$ badaniach fragment rzeczywistości materialnej i kulturowej.

Wyraźnie ukształtowana w dotychczasowych badaniach kognitywnych idea kontinuum pola poznawczego, reprezentowana $w$ badaniach językoznawczych jako kontinuum standardowej metaforyzacji w języku naturalnym oraz jej rozszerzeń $\mathrm{w}$ tekstach poetyckich, została wielostronnie rozbudowana przez Raymonda W. Gibbsa w jego Poetyce umy$s t u^{14}$. Zdaniem Gibbsa, istotą aktywności umysłu jest zdolność do zintegrowanego działania, wyrażającego się w synchronicznym operowaniu tzw. literalnymi i figuratywnymi wzorcami myślenia. Wzorce figuratywne (np. metafora, synekdocha, oksymoron, ironia) są reprezentowane nie tylko w zachowaniach językowych, lecz także naukowych, społecznych i egzystencjalnych. Rozróżnienie wzorców literalności i figuratywności należy, zdaniem Gibbsa, interpretować jako funkcję fenomenologicznego rozróżnienia, dopuszczalnego na poziomie produktów, które winny być ściśle odgraniczone od procesów myślowych. Myślenie figuratywne twierdzi Gibbs - nie ma nic wspólnego z historyczną ewolucją lingwistycznego znaczenia, ani też ze zwykłym (potocznym, podstawowym) rozumieniem języka ${ }^{15}$. Figuratywna wyobraźnia to uporządkowana część proce-

${ }^{14}$ R. W. Gibbs, Jr., The poetics of mind. Figurative thought, language and understanding, Cambridge-New York 1994.

15 Tamże, s. 445-446. 
sów poznawczych, których efekty nie sa zdeterminowane w sensie świadomego wytwarzania produktów o jednoznacznie zaktualizowanych w nich własnościach literalności lub figuratywności.

W koncepcjach umysłu zintegrowanego, zawierających hipotezę synchroniczności liniowych i asocjacyjnych procesów poznawczych, formułowane są także twierdzenia na temat pragmatycznej funkcji metaforyzacji pojęciowej i językowej ${ }^{16}$. Reuven Tsur, autor książki $W$ stronę teorii poetyki kognitywnej (1992) twierdzi, iż językowe środki metaforyzacji znaczeń, stymulując szybkie zmiany mentalne, ułatwiają adaptację do zmiennych warunków środowiska. Równocześnie ułatwiają podmiotowi kontrolę nad spoistością własnej struktury ${ }^{17}$. Adrian Pilkington w Poetic effects (2000) rozszerza perspektywę badań pragmatycznej funkcji tekstu poetyckiego o metrykę, kompozycję, wskaźniki intencji podmiotu autorskiego, relacje intertekstualne. Program kognitywnej poetyki pragmatycznej Pilkingtona zawiera również postulaty wszechstronnego włączenia w badania literaturoznawcze psychologii, mającej umożliwić rekonstrukcję emotywnego podłoża twórczych procesów poznawczych ${ }^{18}$. Przy całym zróżnicowaniu pragmatycznych ujęć standardowej i rozszerzonej teorii metaforyzacji, powtarza się u wielu autorów interesująca hipoteza zależności między poznawczą, adaptacyjną i estetyczną funkcją obrazów mentalnych, interpretowanych w języku za pośrednictwem kompozycji figur stylistycznych. Zdaniem Andrzeja Falkowskiego „podstawową funkcją poznawczego zachowania się człowieka jest zdolność wprowadzania organizacji, symetrii i estetyki w docierającej stymulacji bodźcowej"19. W bardziej radykalnym ujęciu Tsura - estetyczna organizacja stymulacji bodźcowej to efekt koncowy przekształceń mechanizmów adaptacyjnych, rozwijanych pierwotnie w celu przetrwania w środowisku fizycznym i społecznym, a kształtowanych przede wszystkim poprzez pojęciową i językową metaforyzację układu bodźców. Ze względu na formułowanie hipotezy pola metaforycznego na skrzyżowaniu lingwistyki, poetyki, psychologii, antropologii, informatyki i neuronauk, pojęcie pola metaforycznego jest aktualnie najczęściej identyfikowane $\mathrm{z}$ efektami pragmatycznego skanowania reprezentacji obrazującej. Wynikające $\mathrm{z}$ takiej konceptualizacji ograniczenia to

${ }^{16}$ Istotną inspiracją takiego ukierunkowania badań w dziedzinie poetyki kognitywnej była Kognitywna teoria metafory E. R. Mac Cormacka (A cognitive theory of metaphor, Cambridge, MA-London 1989).

${ }^{17} \mathrm{R}$. Tsur, Toward a theory of cognitive poetics, Amsterdam 1992, s. 43-44.

${ }^{18}$ A. Pilkington, Poetic effects. A relevance theory perspective, Amsterdam-Philadelphia 2000, s. 189-192.

${ }^{19}$ A. Falkowski, Relacja podobieństwa w procesach poznawczych. Ekologiczne i informacyjne podejście w psychologii, Lublin 1990, s. 13. 
ujmowanie procesów twórczych w kategoriach procesów przetwarzania ${ }^{20}$. Kontrowersyjnym też, choć konsekwentnie przyjmowanym założeniem, jest prymat zewnętrznej stymulacji bodźcowej nad inspiracją czerpaną $\mathrm{z}$ doświadczenia metafizycznego tła. Być może poetyka transcendentna jest utraconym (lub nie uwzględnianym dostatecznie) wymiarem badań kognitywnych.

${ }^{20}$ Por. interpretację jednego $\mathrm{z}$ aspektów tego ograniczenia w ujęciu: E. Tabakowska, Bliżej wiersza: gramatyka kognitywna jako narzędzie interpretacji tekstu poetyckiego (na przykladzie „Miniatury średniowiecznej” Wislawy Szymborskiej), w: Tekst. Analizy i interpretacje, red. J. Bartmiński i B. Boniecka, Lublin 1998, s. 9-20. 